\title{
KAJIAN MENGENAI PENERIMAAN SISTEM INFORMASI WEB PADAMU NEGERI TERHADAP PENDIDIK DAN TENAGA KEPENDIDIKAN DENGAN MENGGUNAKAN TECHNOLOGY ACCEPTANCE MODEL (TAM)
}

\author{
Ai Umamah \\ AMIK Garut \\ ai.umamah85@gmail.com
}

\section{ABSTRACK}

Islamic Foundation Nuurul Muttaqiin ia a private school in the Garut which is engaged in Islamic education. Charging administration teachers online or Web Padamu Negeri is an information system that is in use at the Islamic Foundation Nuurul Muttaqiin Cisurupan Garut. With the web Padamu Negeri online expect to help filling teacher administration. Charging a good data teacher is needed in order to facilitate schools and teachers to find information. In support of online data entry Padamu Negeri need support of State Information Systems and Technology quality information.

The theory used in this research is the theory butterfly Behaviour Information Systems. This research method using a survey approach and the kind of research is quantitative descriptive. Data collection techniques with interviews, circulate a list of questions and study documentation. Data analysis model used amos 22 version.

The population in this study were teachers in the Islamic Foundation Nuurul Muttaqiin Cisurupan Garut registered active in the web information system Padamu Negeri.Total population is 112 people and the number of samples in the meticulous 103 people. The research hypothesis testing with SEM analysis (Structural Equation Model). SEM is a statistical analysis tools in use to complete multilevel research model simultaneously. From the seven proposed hypothesis shows that there are two hypotheses are not supported. First, the Behavioral Intention to use with Actual technology use in the feel of teachers and there is no real relationship (significant). Secondly, it was felt teachers and no real relationship (significant) between the Perceived usefulness Perceived ease of use.

Keywords: Padamu Negeri Websites, Technoloy Acceptance Model (TAM), Structural Equation Model (SEM).

\begin{abstract}
ABSTRAK
Yayasan Islam Nuurul Muttaqiin adalah sekolah swasta di Garut yang bergerak dalam pendidikan Islam. Pengisian administrasi guru online atau Web Padamu Negeri merupakan sistem informasi yang di gunakan di Yayasan Islam Nuurul Muttaqiin Cisurupan Garut. Dengan web Padamu Negeri online berharap dapat membantu mengisi administrasi guru. Pengisian guru data yang baik diperlukan untuk memfasilitasi sekolah dan guru untuk menemukan informasi. Untuk mendukung entri data online Padamu Negeri memerlukan dukungan informasi Sistem Informasi dan Teknologi Informasi.

Teori yang digunakan dalam penelitian ini adalah teori Butterfly Behavior Information Systems. Metode penelitian ini menggunakan pendekatan survei dan jenis penelitiannya adalah deskriptif kuantitatif. Teknik pengumpulan data dengan wawancara, mengedarkan daftar pertanyaan dan studi dokumentasi. Model analisis data menggunakan versi amos 22 .

Populasi dalam penelitian ini adalah guru di Yayasan Islam Nuurul Muttaqiin Cisurupan Garut yang terdaftar aktif di sistem informasi web Padamu Negeri.Total populasi adalah 112 orang dan jumlah sampel di teliti 103 orang. Pengujian hipotesis penelitian dengan analisis SEM (Structural Equation Model). SEM adalah alat analisis statistik yang digunakan untuk menyelesaikan model penelitian multilevel secara bersamaan. Dari tujuh hipotesis yang
\end{abstract}


diajukan menunjukkan bahwa ada dua hipotesis yang tidak didukung. Pertama, Niat Perilaku untuk digunakan dengan penggunaan teknologi Aktual dalam nuansa guru dan tidak ada hubungan nyata (signifikan). Kedua, itu dirasakan guru dan tidak ada hubungan nyata (signifikan) antara kegunaan yang dirasakan Dirasakan kemudahan penggunaan.

Kata Kunci: Padamu Negeri Websites, Model Penerimaan Technologi (TAM), Structural Equation Model (SEM).

\section{PENDAHULUAN}

\subsection{Latar Belakang Masalah}

TAM merupakan model untuk mengukur aplikasi internet dan TAM merupakan dukungan terhadap www dan TAM juga merupakan prediktor dari kepuasan internet jadi metode tam bisa di gunakan untuk web dan aplikasi yang ada di perusahaan-perusahaan (Nugroho,2009). Analisis mengenai penerimaan sistem informasi web padamu negeri di Yayasan Islam Nuurul Muttaqiin Cisurupan Garut menggunakan model pendekatan kajian prilaku terhadap pengguna informasi dan teknologi.

TAM (Technology Acceptance Model) adalah merupakan metode untuk mengukur pendekatan penerimaan informasi dan teknologi. TAM mempunyai dua faktor yang pertama presepsi manfaat dan kemudakan mengunakan teknologi yang ke dua kemauan untuk penerimaan guru terhadap penerapan teknologi informasi sistem web padamu negeri di Yayasan Islam Nuurul Muttaqiin Cisurupan Garut dengan menggunakan metode penerimaan teknologi (TAM).

Penelitian ini menggunakan metode TAM yang di kenalkan oleh Davis (1989). Dalam model ini ketika pengguna di tawarkan menggunakan sistem yang baru faktor-faktor mempengaruhi keputusan mereka khususnya dalam hal peningkatan kinerja, membebaskan dari kesullitan dalam arti mudah di gunakan (Rahadja et al.,2009).

\subsection{Rumusan Masalah}

Berdasarkan uraian diatas, rumusan masalah yang akan dibahas dalam penelitian ini adalah sebagai berikut :

1. Apakah Ada hubungan yang nyata (signifikan) antara Behavioral Intention to use dengan Actual technology use?

2. Apakah ada hubungan yang nyata (signifikan) antara attitude towards using technology dengan Behavioral Intention to use?

3. Apakah ada hubungan yang nyata (signifikan) antara Perceived usefulness dengan Attitude towards using technology?

4. Apakah ada hubungan yang nyata (signifikan) antara Perceived ease of use dengan Attitude towards using technology?

5. Apakah ada hubungan yang nyata (signifikan) antara Perceived usefulness dengan Perceived ease of use?

6. Apakah ada hubungan yang nyata (signifikan) social influence dengan Perceived usefulness?

7. Apakah ada hubungan yang nyata (signifikan) antara Computer self efficacy dengan Perceived Ease of Use?

\subsection{Maksud dan Tujuan Penelitian}

Maksud dari penelitian ini adalah menganalisis faktor-faktor yang mempengaruhi sistem informasi web Padamu Negeri untuk menunjang aktifitas sekolah, yang bersifat layanan 
terhadap guru dan staf karyawan di TK, SMP dan SMK pada Yayasan Islam Nuurul Muttaqiin Cisurupan Garut.

Tujuan dari penelitian ini adalah mendapatkan analisis penerimaan teknologi berbasi web yang melakukan pengujian model penerimaan teknologi dengan pendekatan Technology Acceptance Model dan meneliti hubungan antar faktor-faktor yang dibangun didalam TAM untuk memprediksi penerimaan pemanfaatan teknologi informasi dilingkungan Yayasan Islam Nuurul Muttaqiin Cisurupan Garut. Manfaat yang bisa diperoleh dari penelitian ini adalah pihak Yayasan Islam Nuurul Muttaqiin Cisurupan Garut dapat mengembangkan pemanfaatan teknologi informasi yang penggunaannya relatif diterima oleh penggunannya sehingga akan meningkatkan minat guru yang berdampak pada tercapainya tujuan administrasi guru dengan baik.

\subsection{Tinjauan Pustaka}

Davis et all (1989) "proposed TAM that the perceived usefulness and the perceived ease of use are important antecedents for information system accept". TAM adalah teori mengenai sistem informasi yang membuat model tentang bagaimana pengguna mau menerima dan menggunakan teknologi. (Morris dan Dillon, 1997). TAM adalah sebuah model untuk memprediksikan bukan mendeskripsikan, yang digunakan untuk memprediksikan penerimaan dari sistem oleh user (Santoso, 2014).

Model TAM di samping menguji validitas, beberapa peneliti juga mengembangkan model TAM dengan menambanhkan beberapa variabel ekternal yang emenerangkan lebih lanjut penyebab (antecedent) dari kegunaan persepsian (perceived usefulness) dn penggunaan persepsian (perceived ease of use).

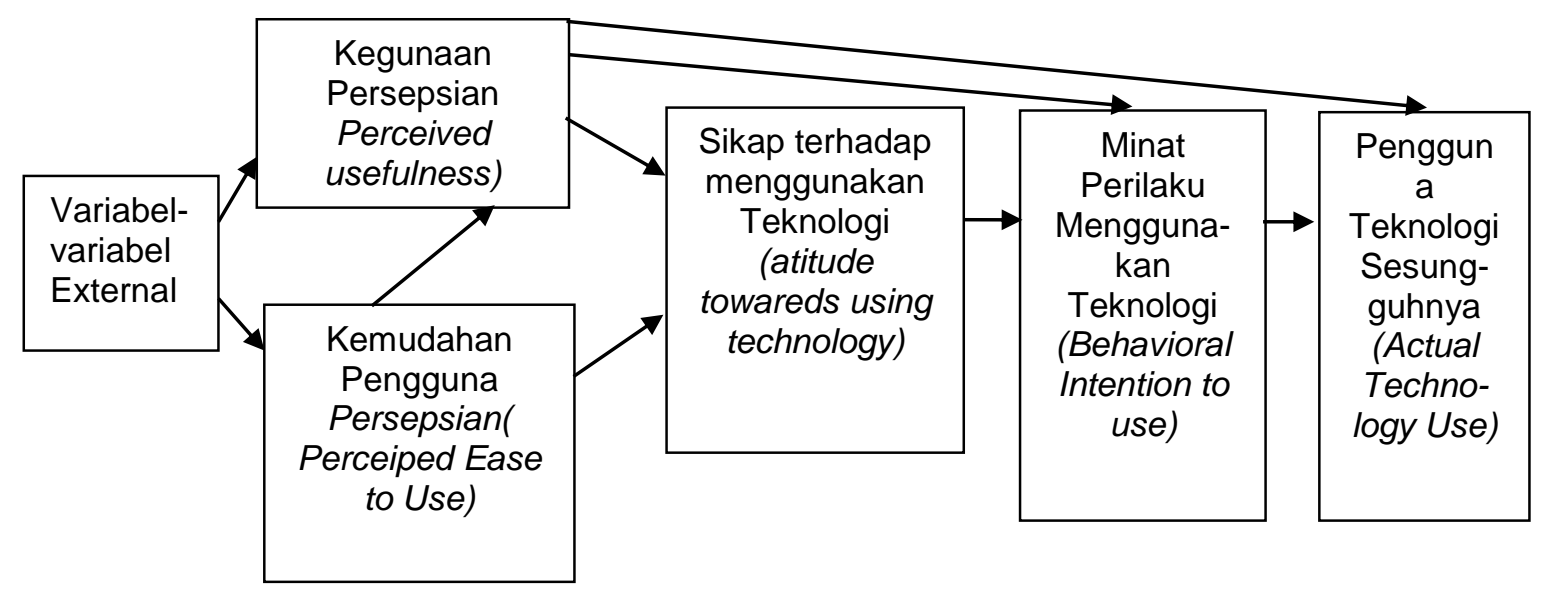

Gambar 1 TAM yang di kembangkan

Peneliti-peneliti yang mencoba mengembangkan model TAM melakukan dengan menambahkan variabel-variabel ekternal. Variabel ekternal yang di gunakan di katagorikan misalnya sebagai variabel-variabel individual, organisasi, kultur, dan karakteristik-karaktrristik tugas.

Lee et al. (2003) dalam (Jugianto, 2007:127), melakukan analisis meta (meta analysis) untuk mengkombinasikan hasil-hasil penelitian TAM sebelumnya. Analisis meta ini menggabungan hasil dari 101 penelitian mulai tahun 1996 sampai juni 2003 yang di publikasikan oleh sistem informasi terkemuka di jurnal-jurnal yang berupa model TAM yang lengkap beserta valiabel-variabel ekternal.

Variabel -variabel ekternal dalam buku Jugianto Sistem Informasi Keprilakuan di antaranya adalah sebagai berikut: 
1. Kerumitan (Complexity)

The degree to which an inovation isvreceived as being difficult to use Roger (1983) Premkumar and fotter (1995), Igbarian et al.(1996) hal 129

2. Keyakinan Sendiri (self efficacy)

The belief that one has the cabability to perform a particular behavior. Bandura (1977) Fenech (1998; Venkatesh and Speier (2000).

3. Computer self efficacy

Dominggus Pirade, A. Karim Saleh, Muhammad Yunus Amar Bandura (1982) dalam Jogiyanto (2007) mendefinisikan self efficacy sebagai pertimbangan tentang seberapa baik seseorang dapat melakukan tindakan-tindakan yang dibutuhkan untuk menghadapi situasi prospektif. Selanjutnya Bandura (1982) seperti dikutip Harrisan dan Rainer (1992) dalam Jogiyanto (2007) mendefinisikan self efficacy sebagai suatu estimasi dari kemampuan seseorang untuk melakukan perilaku sasaran dengan berhasil. Robbins (1998) dalam Tutuk (2009) menemukan bahwa self efficacy yang memadai di dalam diri individu menjadi salah satu faktor yang dapat mempengaruhi hubungan antara penetapan tujuan dan kinerja. Hong et al.(2002) dalam Lindawati (2012) mendefinisikan computer self efficay sebagai suatu evaluasi individual tentang kemampuan-kemampuannya menggunakan komputer. Penelitian Compeau.,dkk (1995) dalam Lindawati(2012) menyatakan computer self efficacy menunjukkan penilaian individu dan kemampuan mereka menggunakan komputer dalam situasi yang berbeda. Pada sejumlah studi sistem informasi, konstruk self efficacy berhubungan dengan pemakaian komputer dan pengembangan skill (Compeau dkk.,1995; Thatcher dkk., 2002) dalam Lindawati (2012). Penelitian mengenai computer self efficacy yang dilakukan terhadap karyawan (intisari. et.al, 1989; Burkhardt dkk .,1990; Compeau dkk.,1995; Harrisson dkk.,1997; Geladak, n.d) dalam Siti (2006) menunjukkan computer self efficacy yang berakibat pada terus meningkatnya kinerja dan inovasi karyawan pada teknologi, mengurangi kecemasan terhadap komputer dan kesempatan mendapatkan promosi jabatan.

4. Kegunaan Objektif (objektive usability)

A construkct that allows for a comparison of systems on the actual level of effect regarding to complete specific task.Car et al. (1980) Venkatesh and Davis (1996); Venkatesh (2000).

5. Norma-norma subjektif/tekanan sosial (Subjective norm/sosial influence)

Person's perception that most people who are important to him think he should or should not perform the behavior in question. Fishben and Ajzen (1975) Malhotra and Galletta(1999); Venkatesh and Morris (2000). Davis menjelaskan bahwa norma-norma sosial tidak memengaruhi hasil akhir.

\section{METODOLOGI}

\subsection{Metode Penelitian}

Metodologi penelitian ini menggunakan metode kuantitatif dengan melakukan tahapantahapan sebagai berikut:

1. Observasi; dilakukan dengan tujuan mendapatkan gambaran nyata dan konkrit mengenai masalah yang akan diteliti. Observasi dilakukan melalui studi literatur mengenai isu yang sedang berkembang di masyarakat khususnya bidang teknologi informasi.

2. Penelitian awal; dilakukan dengan cara melakukan pengamatan secara lebih spesifik di Yayasan Islam Nuurul Muttaqiin dalam pemanfaatan teknologi pada kegiatan pengisian data online. Penelitian diawali dengan melakukan wawancara dengan pihak sekolah, dengan berbagai tingkatan mulai dari yayasan, guru, tata usaha, dan kepala sekolah.

3. Studi Pustaka; dilakukan untuk memberikan gambaran secara teoritis dan bahan acuan untuk penelitian pada Yayasan Islam Nuurul Muttaqiin. 
4. Pengembangan Model penelitian; di lakukan dengan berdasarkan pada teori dan penelitian-penelitian sebelumnya

5. Penyusunan Variabel dengan model yang dikembangkan; disusun variabel berdasarkan konstruk yang telah ditetapkan,

6. Penyusunan Instrumen pengambilan data dalam penelitian ini berupa kuesioner; kuesioner disusun dan dikembangkan sesuai dengan konstruk yang di tetapkan.

7. Uji Coba Kuesioner; yang telah disusun diuji cobakan terhadap sampel terbatas pada guru Yayasan islam Nuurul Muttaqiin sebanyak 30 orang untuk memperoleh pemahaman responden yang sesuai dengan yang diharapkan dalam penelitian ini.

8. Pengambilan data; setelah uji coba kuesioner dinyatakan memadai, maka dilakukan pengambilan data dengan menyebarkan kuesioner kepada pendidik yang dijadikan responden pendidik SMK, pendidik SMP,pendidik TK dan Tenaga Kependidikan SMK, SMP, dan TK Yayasan Islam Nuurul Muttaqiin Garut.

9. Pengolahan data kuesioner yang telah disebarkan kepada responden dan diterima kembali akan diperiksa. Jawaban yang tidak valid, seperti tidak lengkap tidak akan diperiksa lebih lanjut.

10. Analisis dan Pengolahan; dilakukan terhadap sistem informasi web padamu negeri beserta data yang ada dengan cara melakukan survey terhadap pengguna sistem informasi web Padamu Negeri yang sedang berjalan, setelah itu menarik kesimpulan yang dapat di tarik berdasarkan hasil penelitian yang telah di lakukan dan memberikan saran yang berguna bagi penelitian.

\subsection{Populasi dan Sampel}

Populasi merupakan keseluruhan sumber data yang di perlukan dalam suatu penelitian yang lengkap dari satuan-satuan atau individu yang karakteristiknya ingin kita ketahui (Saryono, 2008). populasi dalam penelitian ini adalah seluruh kependidikan dan tenaga kependidikan Yayasan Islam Nuurul Muttaqiin.

Sampel penelitian adalah sebagian dari keseluruhan objek yang diteliti dan di anggap mewakili seluruh populasi dengan kata lain sampel adalah elemen-elemen populasi yang di pilih berdasarkan kemampuan mewakilinya (Saryono, 2008).

\subsection{Jalur}

Jalur (path) adalah informasi yang menunjukkan keterkaitan antara satu konstrak dengan konstrak lainnya. Jalur di dalam SEM terbagi menjadi dua jenis yaitu jalur hubungan kausal dan non kausal. Jalur kausal digambarkan dengan garis dengan panah salah satu ujungnya (J) dan jalur hubungan non kausal ditandai dengan gambar garis dengan dua panah di ujungnya (Q). Namun demikian, meski bentuk garis sama, akan tetapi jika jenis konstrak yang dihubungkan adalah berbeda makna garis berbentuk sama tersebut dapat bermakna berbeda.

\subsection{Uji Validitas dan Uji Reliabilitas}

Menurut Sugiyono (2006) Uji validitas adalah suatu langkah pengujian yang dilakukan terhadap isi (content) dari suatu instrumen, dengan tujuan untuk mengukur ketepatan instrumen yang digunakan dalam suatu penelitian. Tujuan uji validitas untuk mengetahui sejauh mana ketepatan dan kecermatan suatu instrumen pengukuran melakukan fungsi ukurnya. Supaya data yang diperoleh bisa relevan atau sesuai dengan tujuan diadakannya pengukuran tersebut.

Menurut Sukadji (2000) Reliabilitas suatu tes adalah seberapa besar derajat tes mengukur secara konsisten sasaran yang diukur. Reliabilitas dinyatakan dalam bentuk angka, biasanya sebagai koefesien. Koefesien tinggi berarti reliabilitas tinggi. Menurut Anastasia dan Susana (1997) Reliabilitas adalah sesuatu yang merujuk pada konsistensi skor yang dicapai oleh orang yang sama ketika mereka diuji ulang dengan tes yang sama pada kesempatan yang 
berbeda, atau dengan seperangkat butir-butir ekuivalen (equivalent items) yang berbeda, atau di bawah kondisi pengujian yang berbeda. Menurut Husaini (2003) Uji reliabilitas adalah proses pengukuran terhadap ketepatan (konsisten) dari suatu instrumen.

\section{ANALISA DAN PERANCANGAN SISTEM}

\subsection{Identifikasi dan Operasionalisasi Variabel}

Berikut merupakan tabel konstuk dan manifes yang akan peneliti bahas di bab berikutnya:

Tabel 1 Tabel Daftar Variabel Manifest

\begin{tabular}{|c|c|c|c|c|c|}
\hline NO & $\begin{array}{l}\text { KONS- } \\
\text { TRUK }\end{array}$ & DIMENSI & $\begin{array}{l}\text { VARIABEL } \\
\text { MANIFEST }\end{array}$ & SUMBER & $\begin{array}{c}\text { KUESI- } \\
\text { ONER }\end{array}$ \\
\hline 1 & $\begin{array}{l}\text { Perceived } \\
\text { Ease } \\
\text { of Use } \\
\text { (Kemuda- } \\
\text { han } \\
\text { Pengguna } \\
\text { Persepsian) }\end{array}$ & $\begin{array}{l}\text { Perceived ease of use } \\
\text { didefinisikan sebagai } \\
\text { suatu ukuran di mana } \\
\text { seseorang percaya } \\
\text { bahwa web padamu } \\
\text { negeri dalam } \\
\text { pengisian data guru } \\
\text { membawa suatu } \\
\text { kemudahan bagi } \\
\text { pengguna. }\end{array}$ & $\begin{array}{l}\text { 1. Pekerjaan } \\
\text { lebih cepat } \\
\text { 2. Bermanfaat } \\
\text { 3. Produktifitas } \\
\text { 4. Efektifitas } \\
\text { 5. Kinerja } \\
\text { pekeerjaan }\end{array}$ & $\begin{array}{l}\text { Davis, } \\
\text { 1989: } 320 \\
\text { Venkatesh } \\
\text { and Davis } \\
(1996)\end{array}$ & $\begin{array}{l}\text { PE1 } \\
\text { PE2 } \\
\text { PE3 } \\
\text { PE4 } \\
\text { TPE5 }\end{array}$ \\
\hline 2 & $\begin{array}{l}\text { Perceived } \\
\text { Usefulness } \\
\text { (Kegunaan } \\
\text { Persepsian) }\end{array}$ & $\begin{array}{l}\text { Perceived usefulness } \\
\text { didefinisikan sebagai } \\
\text { suatu ukuran di } \\
\text { mana penggunaan } \\
\text { web padamu negeri } \\
\text { dalam pengisisan data } \\
\text { dipercaya akan } \\
\text { mendatangkan } \\
\text { manfaat bagi orang } \\
\text { yang } \\
\text { menggunakannya }\end{array}$ & $\begin{array}{l}\text { 1. Mudah di } \\
\text { pelajari } \\
\text { 2. Mudah di } \\
\text { kontrol } \\
\text { 3. Mudah di } \\
\text { mengerti dan } \\
\text { jelas } \\
\text { 4. Mudah di } \\
\text { kuasai } \\
\text { 5. Mudah di } \\
\text { gunakan } \\
\text { 6. Fleksible }\end{array}$ & $\begin{array}{l}\text { Davis et } \\
\text { al., (1989) } \\
\text { David FD } \\
(1986)\end{array}$ & $\begin{array}{l}\text { PU1 } \\
\text { PU2 } \\
\text { PU3 } \\
\text { PU4 } \\
\text { PU5 } \\
\text { PU6 }\end{array}$ \\
\hline 3 & $\begin{array}{l}\text { Attitude } \\
\text { toward } \\
\text { using } \\
\text { (Sikap } \\
\text { terhadap } \\
\text { mengguna- } \\
\text { kan } \\
\text { Teknologi) }\end{array}$ & $\begin{array}{l}\text { Attitude toward using } \\
\text { dikonsepkan sebagai } \\
\text { sikap terhadap } \\
\text { penggunaan sistem } \\
\text { yang berbentuk } \\
\text { penerimaan atau } \\
\text { penolakan sebagai } \\
\text { dampak bila } \\
\text { seseorang } \\
\text { menggunakan suatu } \\
\text { teknologi dalam } \\
\text { pekerjaannya }\end{array}$ & $\begin{array}{l}\text { 1. Menyenangk } \\
\text { an } \\
\text { 2. Ide yang } \\
\text { bagus } \\
\text { 3. Dinilai perlu } \\
\text { 4. Suka } \\
\text { mengguna- } \\
\text { kan } \\
\text { 5. Ide yang } \\
\text { bijaksana }\end{array}$ & $\begin{array}{l}\text { Davis et al., } \\
(1989),\end{array}$ & $\begin{array}{l}\text { ATU1 } \\
\text { ATU2 } \\
\text { ATU3 } \\
\text { ATU4 } \\
\text { ATU5 }\end{array}$ \\
\hline 4 & $\begin{array}{l}\text { Actual } \\
\text { technology } \\
\text { use }\end{array}$ & $\begin{array}{l}\text { Actual usage } \\
\text { dikonsepkan dalam } \\
\text { bentuk pengukuran } \\
\text { terhadap frekuensi dan }\end{array}$ & $\begin{array}{l}\text { 1. Kontinu } \\
\text { 2. Sering } \\
\text { Mengguna- } \\
\text { kan }\end{array}$ & $\begin{array}{l}\text { (Davis, } \\
\text { 1989: 322) }\end{array}$ & $\begin{array}{l}\text { AU1 } \\
\text { AU2 }\end{array}$ \\
\hline
\end{tabular}




\begin{tabular}{|c|c|c|c|c|c|}
\hline NO & $\begin{array}{l}\text { KONS- } \\
\text { TRUK }\end{array}$ & DIMENSI & $\begin{array}{l}\text { VARIABEL } \\
\text { MANIFEST }\end{array}$ & SUMBER & $\begin{array}{c}\text { KUESI- } \\
\text { ONER }\end{array}$ \\
\hline & $\begin{array}{l}\text { (pengguna } \\
\text { teknologi } \\
\text { sesungguhn } \\
\text { ya) }\end{array}$ & $\begin{array}{l}\text { durasi waktu } \\
\text { penggunaan teknologi }\end{array}$ & $\begin{array}{l}\text { 3. Mengguna- } \\
\text { kan untuk } \\
\text { aktivitas } \\
\text { Pengisian } \\
\text { data }\end{array}$ & & AU3 \\
\hline 5 & $\begin{array}{l}\text { Behavioalr } \\
\text { intention of } \\
\text { use } \\
\text { (Minat } \\
\text { prilaku } \\
\text { mengguna- } \\
\text { kan } \\
\text { teknologi } \\
\end{array}$ & $\begin{array}{l}\text { Suatu keinginan } \\
\text { seseorang untuk } \\
\text { melakukan suatu } \\
\text { perilaku menggunakan } \\
\text { teknologi }\end{array}$ & $\begin{array}{l}\text { 1.Menggunaan } \\
\text { 2.Niat memakai } \\
\text { 3.Mamperkira- } \\
\text { kan dan } \\
\text { meggunakan }\end{array}$ & $\begin{array}{l}\text { (Davis, } \\
\text { 1989: 321), } \\
\text { taylor,1995; } \\
\text { Venkatesh } \\
\text { dan Davis, } \\
\text { Jogiyanto } \\
2007\end{array}$ & $\begin{array}{l}\text { PUS1 } \\
\text { PUS2 } \\
\text { PUS3 }\end{array}$ \\
\hline 6 & $\begin{array}{l}\text { Computer } \\
\text { self efficacy } \\
\text { (keyakinan } \\
\text { sendiri) }\end{array}$ & $\begin{array}{l}\text { Computer Self } \\
\text { Efficacy dipandang } \\
\text { sebagai salah satu } \\
\text { variabel yang penting } \\
\text { untuk studi perilaku } \\
\text { individual dalam } \\
\text { bidang teknologi } \\
\text { informasi. }\end{array}$ & $\begin{array}{l}\text { 1. Keyakinan } \\
\text { 2.Harapan } \\
\text { sekolah } \\
\text { 3. Dorongan } \\
\text { dari } \\
\text { Dukungan } \\
\text { dari pihak } \\
\text { sekolah } \\
\text { 4.Dorongan } \\
\text { dari sesama } \\
\text { rekan } \\
\text { 5. Kecemasan }\end{array}$ & $\begin{array}{l}\text { Ni Luh } \\
\text { Nyoman } \\
\text { Herina Devi } \\
\text { I Wayan } \\
\text { uartana } \\
2014\end{array}$ & $\begin{array}{l}\text { CSE1 } \\
\text { CSE2 } \\
\text { CSE3 } \\
\text { CSE4 } \\
\text { CSE5 }\end{array}$ \\
\hline 7 & $\begin{array}{l}\text { Social } \\
\text { Influence. } \\
\text { (Tekanan } \\
\text { sosial) }\end{array}$ & $\begin{array}{l}\text { sebagai sejauh mana } \\
\text { individu } \\
\text { mempersepsikan } \\
\text { kepentingan yang } \\
\text { dipercaya oleh orang } \\
\text { lain yang akan } \\
\text { mempengaruhinya } \\
\text { menggunakan sistem } \\
\text { baru. }\end{array}$ & $\begin{array}{l}\text { 1.Dorongan dari } \\
\text { pihak sekolah } \\
\text { 2. Kegunaan } \\
\text { 3. Meningkatkan } \\
\text { evaluasi } \\
\text { pekerjaan } \\
\text { 4.Bangga } \\
\text { menggunaka } \\
\text { 5.Bisa } \\
\text { menjelaskann } \\
\text { terhadap } \\
\text { rekan } \\
\text { 6. membantu } \\
\text { menjelaskan }\end{array}$ & $\begin{array}{l}\text { Jogiyanto.2 } \\
007, \\
\text { Venkatesh } \\
\text { and Morris } \\
(2000)\end{array}$ & $\begin{array}{l}\text { SI1 } \\
\text { SI2 } \\
\text { SI3 } \\
\\
\text { SI4 } \\
\text { SI5 } \\
\\
\end{array}$ \\
\hline
\end{tabular}

\subsection{Hasil Uji Kelayakan Model}

Uji kelayakan model di lakukan dengan menggunakan SEM yang sekaligus di gunakan untuk menganalisis hipotesis yang di ajukan. Berdasarkan hasil olahan data dengan menggunakan prosedur estimasi maximum likelihood terlihat besarnya nilai fuction of log likelihood yaitu 2451,8. sehingga model yang dianalisis secara keseluruhan (overall fit) yang berarti ada perbedaan model secara teoritis dan empiris atau lapangan (Supriyadi: 2014). Untuk analisis SEM ini perlu modifikasi model. Evaluasi nilai goodness of fit dari model penelitian yang diajukan dapat dilihat pada tabel berikut ini: 
Tabel 2 Goodness of Fit Index

\begin{tabular}{|l|l|l|}
\hline \multicolumn{1}{|c|}{$\begin{array}{c}\text { Goodness of Fit } \\
\text { Index }\end{array}$} & \multicolumn{1}{c|}{ Cut of Value } & Keterangan \\
\hline Probability & $>0,05$ & 0,000 \\
\hline NCP & Diharapkan kecil & 1041,348 \\
\hline RMR & $\leq 0,05$ & \\
\hline $\begin{array}{l}\text { Hasil goodness of fit } \\
\text { Model RMSEA }\end{array}$ & $\begin{array}{l}\leq 0,08 \text { good fit } \\
=0,05 \text { close fit }\end{array}$ & 0,15 \\
\hline ECVI & Diharapkan kecil & 16,719 \\
\hline TLI & $>0,95$ & 0,539 \\
\hline NFI & $\begin{array}{l}0,90 \\
0,80 \text { sd } 0,90 \text { marginal fit }\end{array}$ & 0,524 \\
\hline RFI & $\begin{array}{l}0,90 \\
0,80 \text { sd } 0,90 \text { marginal fit }\end{array}$ & 0,449 \\
\hline IFI & $\begin{array}{l}0,90 \\
0,80 \text { sd } 0,90 \text { marginal fit }\end{array}$ & 0,613 \\
\hline CFI & $\begin{array}{l}0,90 \\
0,80 \text { sd } 0,90 \text { marginal fit }\end{array}$ & 0,602 \\
\hline CMIN/DF & $<2,00$ & 3,284 \\
\hline PCFI & Diharapkan besar & 0,520 \\
\hline PNFI & Diharapkan besar & 0,452 \\
\hline
\end{tabular}

Berdasarkan tabel diatas, keseluruhan pengukuran goodness of fit di atas mengidentifikasikan bahwa masih terdapat model yang belum goodness of fit atau memenuhi syarat. Hal ini di karenakan data hasil penelitian memiliki nilai covarian minus. Meskipun demikian, model fit yang dihasilkan mendekati nilai yang diharapkan.

\subsection{Hasil Pengujian Hipotesis}

Pengujian hipotesis dilakukan dengan menggunakan Structural Equation Modeling (SEM) dengan bantuan program AMOS versi 22. Analisis ini dilihat dari signifikansi besaran regression weight model dan standardized regression weight yang dapat dilihat pada tabel berikut ini :

Tabel 3 Regression Weight

Regression Weights: (Group number 1 - Default model)

\begin{tabular}{|c|c|c|c|c|c|c|c|}
\hline & & & Estimate & S.E. & C.R. & $\mathrm{P}$ & Label \\
\hline$\overline{\mathrm{PE}}$ & <--- & CSE & .396 & .175 & 2.258 & .024 & \\
\hline PU & $<---$ & PE & .124 & .108 & 1.144 & .253 & \\
\hline PU & $<--$ & SI & 1.342 & .284 & 4.716 & $* * *$ & \\
\hline ATUT & $<---$ & PU & .731 & .104 & 7.041 & $* * *$ & \\
\hline ATUT & $<--$ & PE & .332 & .096 & 3.477 & $* * *$ & \\
\hline $\mathrm{BIU}$ & $<--$ & ATUT & .676 & .115 & 5.886 & $* * *$ & \\
\hline ATU & $<---$ & BIU & .049 & .056 & .864 & .387 & \\
\hline
\end{tabular}

Berdasarkan tabel diatas dapat diuraikan hasil pengujian hipotesis sebagai berikut:

1. H1 : Tidak terdapat hubungan yang nyata (signifikan) antara Behavioral Intention to use dengan Actual technology use

Hipotesa ini bertujuan untuk menguji apakah Behavioral Intention to use (minat prilaku menggunakan) memiliki pengaruh terhadap Actual technology use (pengguna teknologi 
sesungguhnya). Berdasarkan perhitungan pada tabel 4.18, uji signifikansi terhadap hipotesis 1 tidak terbukti secara signifikan, karena di peroleh nilai probabilitas 0,387 atau lebih besar dari 0,05 yang berarti tidak signifikan pada tarap signifikansi 5\%, dengan nilai koefisien jalur 0,049 .

2. H2 : Terdapat hubungan yang nyata (signifikan) antara attitude towards using technology dengan Behavioral Intention to use

Hipotesa ini bertujuan untuk menguji apakah attitude towards using technology (sikap terhadap menggunakan teknologi) memiliki pengaruh terhadap Behavioral Intention to use (minat prilaku menggunakan). Berdasarkan perhitungan pada tabel 4.18, uji signifikansi terhadap hipotesis 2 terbukti secara signifikan, karena di peroleh nilai probabilitas 0,000 atau lebih kecil dari 0,05 yang berarti signifikan pada tarap signifikansi 5\%, dengan nilai koefisien jalur 0,676.

3. H3 : Ada hubungan yang nyata (signifikan) antara Perceived usefulness dengan Attitude towards using technology

Hipotesa ini bertujuan untuk menguji apakah Perceived usefulness (kegunaan persepsian) memiliki pengaruh terhadap attitude towards using technology (sikap terhadap menggunakan teknologi). Berdasarkan perhitungan pada tabel 4.18, uji signifikansi terhadap hipotesis 3 terbukti secara signifikan, karena di peroleh nilai probabilitas 0,000 atau lebih kecil dari 0,05 yang berarti signifikan pada tarap signifikansi 5\%, dengan nilai koefisien jalur 0,731 .

4. H4 : Ada hubungan yang nyata (signifikan) antara Perceived Ease of Use dengan Attitude towards using technology

Hipotesa ini bertujuan untuk menguji apakah Perceived Ease of Use (persepsian kemudahan pengguna) memiliki pengaruh terhadap attitude towards using technology (sikap terhadap menggunakan teknologi). Berdasarkan perhitungan pada tabel 4.18 , uji signifikansi terhadap hipotesis 4 terbukti secara signifikan, karena di peroleh nilai probabilitas 0,000 atau lebih kecil dari 0,05 yang berarti signifikan pada tarap signifikansi $5 \%$, dengan nilai koefisien jalur 0,332.

5. H5 : Tidak Ada hubungan yang nyata (signifikan) antara Perceived usefulness dengan Perceived ease of use

Hipotesa ini bertujuan untuk menguji apakah Perceived usefulness (persepsian kegunaan pengguna) memiliki pengaruh terhadap Perceived ease of use (persepsi kemudahan pengguna). Berdasarkan perhitungan pada tabel 4.18, uji signifikansi terhadap hipotesis 5 tidak terbukti secara signifikan, karena di peroleh nilai probabilitas 0,253 atau lebih besar dari 0,05 yang berarti tidak signifikan pada tarap signifikansi $5 \%$, dengan nilai koefisien jalur 0,124 .

6. H6 : Ada hubungan yang nyata (signifikan) social influence dengan Perceived usefulness

Hipotesa ini bertujuan untuk menguji apakah social influence ( tekanan sosial) memiliki pengaruh terhadap Perceived usefulness (persepsian kegunaan pengguna) . Berdasarkan perhitungan pada tabel 4.18, uji signifikansi terhadap hipotesis 6 terbukti secara signifikan, karena di peroleh nilai probabilitas 0,000 atau lebih kecil dari 0,05 yang berarti signifikan pada tarap signifikansi 5\%, dengan nilai koefisien jalur 1,342.

7. H7 : Ada hubungan yang nyata (signifikan) antara Computer self efficacy dengan Perceived Ease of Use.

Hipotesa ini bertujuan untuk menguji apakah Computer self efficacy (keyakinan Sendiri) memiliki pengaruh terhadap Perceived Ease of Use (persepsian kemudahan pengguna). Berdasarkan perhitungan pada tabel 4.18 , uji signifikansi terhadap hipotesis 7 terbukti 
secara signifikan, karena di peroleh nilai probabilitas 0,024 atau lebih kecil dari 0,05 yang berarti signifikan pada tarap signifikansi 5\%, dengan nilai koefisien jalur 0,396.

\subsection{Hasil Pengujian Model yang Sudah di Hapus}

Uji kelayakan model di lakukan dengan menggunakan SEM yang sekaligus di gunakan untuk menganalisis hipotesis yang di ajukan. Hasil pengujian model melalui model pengujian structural adalah seperti yang di tampilkan pada gambar berikut ini.

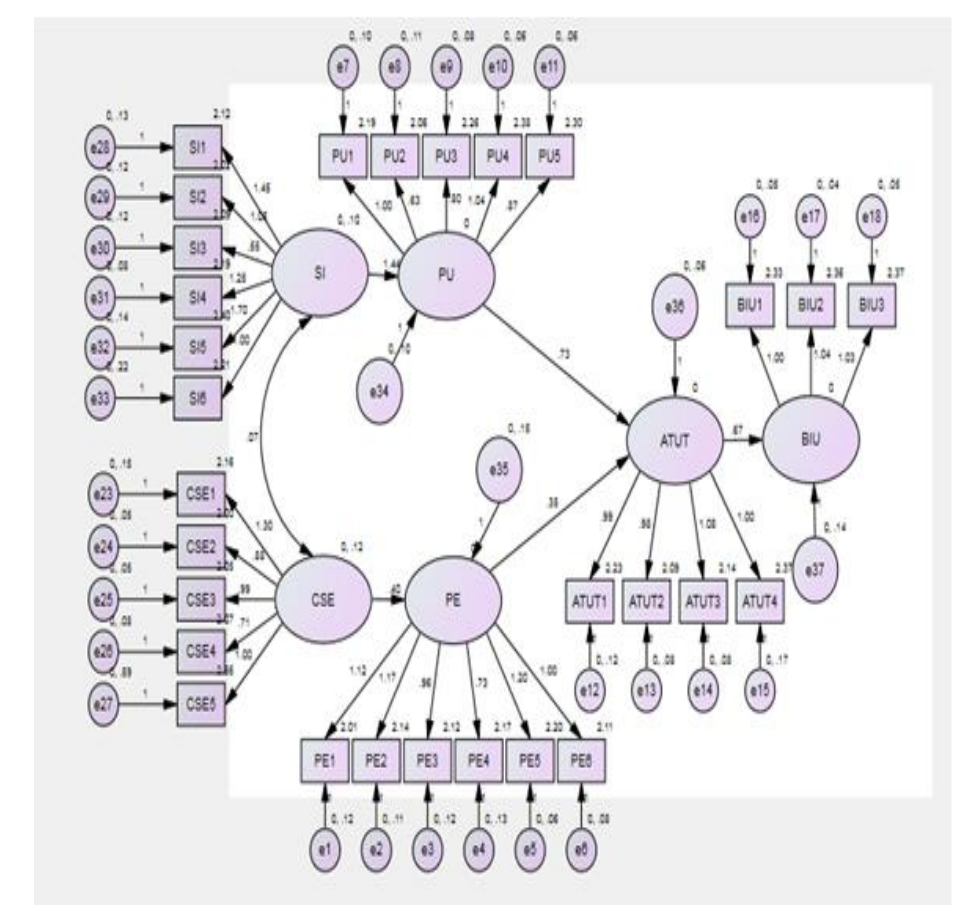

Gambar 3 Hasil Pengujian Model yang Sudah di Trimming

Berdasarkan gambar diatas, hasil olahan data terlihat besarnya nilai probability pada default model yaitu 0,000 sehingga model yang dianalisis secara keseluruhan (overall fit) yang berarti ada perbedaan model secara teoritis dan empiris atau lapangan (Supriyadi: 2014). Untuk analisis SEM ini perlu modifikasi model. Evaluasi nilai goodness of fit dari model penelitian yang diajukan dapat dilihat pada tabel berikut ini:

Tabel 4 Hasil goodness of fit Model

\begin{tabular}{|l|l|l|}
\hline $\begin{array}{l}\text { Goodness of Fit } \\
\text { Index }\end{array}$ & \multicolumn{1}{|c|}{ Cut of Value } & Keterangan \\
\hline Chi-Square & Diharapkan kecil & 1301 \\
\hline Probabilitas & $>0,05$ & 0,000 \\
\hline NCP & Diharapkan kecil & 930,04 \\
\hline RMSEA & $\begin{array}{l}\leq 0,08 \text { good fit } \\
=0,05 \text { close fit }\end{array}$ & 0,157 \\
\hline ECVI & Diharapkan kecil & 14,579 \\
\hline TLI & $>0,95$ & 0,564 \\
\hline NFI & $\begin{array}{l}0,90 \\
0,80 \text { sd } 0,90 \text { marginal fit }\end{array}$ & 0,557 \\
\hline RFI & $\begin{array}{l}0,90 \\
0,80 \text { sd } 0,90 \text { marginal fit }\end{array}$ & 0,481 \\
\hline IFI & $\begin{array}{l}0,90 \\
0,80 \text { sd } 0,90 \text { marginal fit }\end{array}$ & 0,638 \\
\hline
\end{tabular}




\begin{tabular}{|l|l|l|}
\hline CFI & 0,90 & 0,628 \\
& 0,80 sd 0,90 marginal fit & \\
\hline CMIN/DF & $<2,00$ & 3,507 \\
\hline PCFI & Diharapkan besar & 0,536 \\
\hline PNFI & Diharapkan besar & 0,473 \\
\hline
\end{tabular}

Berdasarkan tabel diatas, keseluruhan pengukuran goodness of fit di atas mengidentifikasikan bahwa masih terdapat model yang belum goodness of fit atau memenuhi syarat. Hal ini di karenakan data hasil penelitian memiliki nilai covarian minus. Meskipun demikian, model fit yang dihasilkan mendekati nilai yang diharapkan.

\subsection{Hasil Pengujian Hipotesa Model Kedua}

Pengujian hipotesis model ke dua dilakukan dengan menggunakan Structural Equation Modeling (SEM) dengan bantuan program AMOS versi 22. Analisis ini dilihat dari signifikansi besaran regression weight model dan standardized regression weight, di bawah ini merupakan hipotesa hasil uji model yang ke dua adalah sebagai berikut:

1. H2 : Terdapat hubungan yang nyata (signifikan) antara attitude towards using technology dengan Behavioral Intention to use

Hipotesa ini bertujuan untuk menguji apakah attitude towards using technology (sikap terhadap menggunakan teknologi) memiliki pengaruh terhadap Behavioral Intention to use (minat prilaku menggunakan). Berdasarkan perhitungan pada tabel 4.18, uji signifikansi terhadap hipotesis 2 terbukti secara signifikan, karena di peroleh nilai probabilitas 0,000 atau lebih kecil dari 0,05 yang berarti signifikan pada tarap signifikansi 5\%, dengan nilai koefisien jalur 0,676 .

2. H3 : Ada hubungan yang nyata (signifikan) antara Perceived usefulness dengan Attitude towards using technology

Hipotesa ini bertujuan untuk menguji apakah Perceived usefulness (kegunaan persepsian) memiliki pengaruh terhadap attitude towards using technology (sikap terhadap menggunakan teknologi). Berdasarkan perhitungan pada tabel 4.18, uji signifikansi terhadap hipotesis 3 terbukti secara signifikan, karena di peroleh nilai probabilitas 0,000 atau lebih kecil dari 0,05 yang berarti signifikan pada tarap signifikansi 5\%, dengan nilai koefisien jalur 0,731 .

3. H4 : Ada hubungan yang nyata (signifikan) antara Perceived Ease of Use dengan Attitude towards using technology

Hipotesa ini bertujuan untuk menguji apakah Perceived Ease of Use (persepsian kemudahan pengguna) memiliki pengaruh terhadap attitude towards using technology (sikap terhadap menggunakan teknologi). Berdasarkan perhitungan pada tabel 4.18, uji signifikansi terhadap hipotesis 4 terbukti secara signifikan, karena di peroleh nilai probabilitas 0,000 atau lebih kecil dari 0,05 yang berarti signifikan pada tarap signifikansi $5 \%$, dengan nilai koefisien jalur 0,332 .

4. H6 : Ada hubungan yang nyata (signifikan) social influence dengan Perceived usefulness

Hipotesa ini bertujuan untuk menguji apakah social influence ( tekanan sosial) memiliki pengaruh terhadap Perceived usefulness (persepsian kegunaan pengguna) . Berdasarkan perhitungan pada tabel 4.18, uji signifikansi terhadap hipotesis 6 terbukti secara signifikan, karena di peroleh nilai probabilitas 0,000 atau lebih kecil dari 0,05 yang berarti signifikan pada tarap signifikansi 5\%, dengan nilai koefisien jalur 1,342.

5. H7 : Ada hubungan yang nyata (signifikan) antara Computer self efficacy dengan Perceived Ease of Use. 
Hipotesa ini bertujuan untuk menguji apakah Computer self efficacy (keyakinan Sendiri) memiliki pengaruh terhadap Perceived Ease of Use (persepsian kemudahan pengguna). Berdasarkan perhitungan pada tabel 4.18, uji signifikansi terhadap hipotesis 7 terbukti secara signifikan, karena di peroleh nilai probabilitas 0,024 atau lebih kecil dari 0,05 yang berarti signifikan pada tarap signifikansi 5\%, dengan nilai koefisien jalur 0,396.

\section{PENUTUP}

\subsection{Kesimpulan}

Berdasarkan hasil pengujian terhadap penelitian yang di lakukan di Yayasan Islam Nuurul Muttaqiin Cisurupan Garut tentanh penerimaman sistem informasi web padamu neeri terhadap pendidik dan tenaga tenaga kependidikan dengan menggunakan pendekatan model penerimaan Technology Accptance Model dengan menggunakan software Amos versi 22, maka kesimpulan yang dapat di ambil adalah terdapat tujuh kontruk atau variabel yang di ambil oleh peneliti yang di anggap peneliti dapat menganalisis penerimaan sistem informasi web padamu negeri dalam pengisisan data online di Yayasan Islam Nuurul Muttaqiin Cisurupan Garut. Kontruk tersebut adalah Perceived Ease of Use (Persepsian Kemudahan Pengguna), Perceived Usefulness (Kegunaan Persepsian), Attitude toward using Technology (Sikap terhadap menggunakan Teknologi), Actual technology use (pengguna teknologi sesungguhnya), Behavioral intention of use (minat prilaku menggunakan tekhnologi), computer self efficacy (keyakinan sendiri), Social Influence (Tekanan sosial). Dengan tujuan hipotesa yang di buat untuk dapat menganalisis penerimaan sistem infomasi web Padamu Negeri.

Setelah di lakukan uji kuesioner yang releabel dan valid, di sebarkan kuesioner kepada pendidik dan tenaga kependidikan Yayasan Islam Nuurul Muttaqiin Cisurupan Garut. Data yang di peroleh dari kuesioner memberikan hipotesa dari model konseptual penelitian. Hasil dari hipotesa tersebut adalah sebagai berikut:

1. H1 : Tidak terdapat hubungan yang nyata (signifikan) antara Behavioral Intention to use dengan Actual technology use

2. H2 : Terdapat hubungan yang nyata (signifikan) antara attitude towards using technology dengan Behavioral Intention to use

3. H3 : Ada hubungan yang nyata (signifikan) antara Perceived usefulness dengan Attitude towards using technology

4. H4 : Ada hubungan yang nyata (signifikan) antara Perceived Ease of Use dengan Attitude towards using technology

5. H5 : Tidak Ada hubungan yang nyata (signifikan) antara Perceived usefulness dengan Perceived ease of use

6. H6 : Ada hubungan yang nyata (signifikan) social influence dengan Perceived usefulness

7. H7 : Ada hubungan yang nyata (signifikan) antara Computer self efficacy dengan Perceived Ease of Use.

Pada penelitian ini kontruk minat prilaku menggunakan teknologi web Padamu Negeri tidak ada hubungan yang nyata (signifikan) terhadap pengguna teknologi web padamu negeri sesungguhnya. Hal ini mungkin terjadi karena pendidik dan tenaga kependidikan merasa bahwa minat menggunakan teknologi web padamu negeri, mereka tidak merasakan ada kaitannya dengan pengguna teknologi web padamu negeri. Selain itu konstuk persepsi kegunaan dengan persepsi kemudahan pengguna tidak ada hubungan yang nyata (signifikan). Hal ini mungkin terjadi karena pendidik dan tenaga kependidikan merasa bahwa kegunaan web padamu negeri tidak berpengaruh, ketika mereka menggunakan web padamu negeri banyak kendala yang terjadi dalam pelaksanaan pengisian data online, baik dari segi teknologi, 
perangkat pendukung, maupun sumber daya manusianya sehingga mereka tidak merasakan kemudahan dalam penggunaan sistem informasi pengisian data online.

\subsection{Saran}

Saran-saran yang dapat di berikan berdasarkan penelitian yang telah di lalukan adalah sebagai berikut:

1. Kontruk yang mempengaruhi sikap terhadap menggunakan teknologi yaitu minat prilaku menggunakan teknologi, persepsi kegunaan, persepsi kemudahan pengguna, keyakinan sendiri, tekanan sosial. Oleh karena itu perancangan strategi penggunaan sistem informasi web padamu negeri di Yayasan Islam Nuurull Muttaqiin Cisurupan Garut harus memperhatikan kontruk-konrtuk tersebut untuk meningkatkan kesuksesan penggunaan pebngisian data online di Yayasan Islam Nuurull Muttaqiin Cisurupan Garut.

2. Sumber daya pendukung pelaksana (teknologi, peralatan dan manusia) harus lebih di tingkatkan untuk menunjang pelaksanaan pengisian data online yang lebih baik.

3. Untuk peneliti lanjutan dapat di tambahkan kontruk atau variabel lain yang ikut mempengaruhi penerimaan terhadap sistem pengisian data online atau melakukan penggabungan beberapa model penerimaan teknologi lainnya yang dapat menggambarkan penerimaan yang semakin baik lagi.

\section{DAFTAR PUSTAKA}

Ajzen, I., dan Fishbein, M., (1980). Understanding Attitudes and Predicting Social Behavior, Prentice-Hall. Englewood Scliffs, NJ.

Bandura, A. (1997). Self-efficacy: The Exercise of Control. Worth Publishers.

Davis, F.D.(1989). Perceived Usefulness, Perceived Ease of Use dan Acceptance of Information System Technology. MIS Quartery. 13 (3), 319-339.

Devi, S dan Suartana, W. (2014). Analisis Technology Acceptance Model (TAM) terhadap Penggunaan Sistem Informasi di Nusa Dua Beach Hotel dan Spa. Jurnal Akuntansi Universitas Udayana. 6.(1),167-184.

Adiwibowo, L et al.,(2005). Analisis Plilakun Pengguna Teknologi Informasi Pada Perguruan Tingggi Berstatus BHMN (Studi Penerapan Teknologi Informasi pada FPEB Universitas Pendidikan Indonesia.

Jogiyanto.(2007). Sistem Informasi keprilakuan. Yogyakarta: Andi.

Herina,Ni Luh Nyoman dan Devi I Wayan Suartana.(2014). Analisis Technology Acceptance Model (TAM) terhadap Penggunaan Sistem Informasi.

http://padamu.siap.web.id 09 Pebruari 2015 jam 09.18

Mardi.(2013).Pengaruh sistem Informasi Manajemen Pegawai terhadap Kualitas Pelayanan Administrasi Kepegawaian di Badan Kepegawaian Daerah BKB Kota Samarinda. ejournal.ip.fisip.unmul. 1, (2), 535 - 547.

Muntianah,T.S et al.,(2012). Pengaruh minat prilaku terhadap actual use technology informasi dengan pendekatan TAM. 
Nugroho, M.A. (2009). Model Penerimaan E- Commerce Jurnal Pendidikan Akuntasi Indonesia JPAI. 7 (2), 46-55.

Rahardja, U et al.,(2009). Analisis Kinerjs Student Information Service Menggunakan Technology Acceptance Model (TAM) Jurnal. 2 (2), 1978-8282.

Santoso, S.(2014). Konsep Dasar dan Aplikasi SEM dengan AMOS 22, Jakatra: PT Elex Media Komputindo.

, B.(2012). Pengaruh perceived usefulness, perceived ease of use, dan perceived enjoyment terhadap penerimaan teknologi informasi. Jurnal Studi Akuntansi Indonesia. 1 (1), 1-15.

Siregar, K R.(2011). Kajian Mengenai Penerimaan Teknologi dan Informasi Menggunakan Technology Accaptance Model (TAM). Jurnal Rekayasa Telkom Institute of Management. 4 (1), 27-32.

, K R.(2011). Kajian Mengenai Penerimaan Teknologi dan Informasi Menggunakan Technology Accaptance Model (TAM). Jurnal Rekayasa Telkom Institute of Management. 4 (1), 27-32.

Supriyadi, E.(2014). SPSS dan AMOS Statistical Data Analysis. Jakarta: In Media

Sudjana. (2005). Metoda Statistik edisi 6. Bandung:Tarsito

Sundayana.(2015).Statistika Penelitian Pendidikan. Bandung: Alfabeta .(2010).Komputasi Data Statistik: STKIP Garut Press.

Surachman, A.(2008). Analisis penerimaan Sistem Informasi Perpustakaan (SIPUS) Terpadu Versi 3 di Lingkungan Universitas Gadjah Mada. Perpustakaan Digital UIN Sunan Kalijaga.: Yogyakarta.

Suryono.(2008). Metodologi Penelitian Kesehatan Penuntun Praktis Bagi Pemula

Venkatesh, V., dan F. D. Davis.(1996). A Model of the Perceived Ease of Use Development and Test. Decision Sciences, 27/3: 451-481

Venkatesh, V., dan Michael G. Morris.(2000). Why Don't Men Ever Stop to Ask for Directions? Gender, Social Influence, and Their Role in Technology Acceptance and Usage Behavior. MIS Quarterly, 24/1

Widhiarso,W.(2009).Pelatihan Analisis SEM Melalui AMOS Fakultas Psikologi UGM.

Widiana, M.E.(2012). Penggunaan Teknologi Internet dalam Sistem Penjualan Online untuk Meningkatkan Kepuasan dan Pembelian Berulang Produk Batik pada Usaha Kecil dan menengah. Jurnal Manajemen dan Kewirausahaan 14(1), 71-81. 
Yuadi, I.(2009). Analisis Technology Acceptance Model terhadap Perpustakaan Digital dengan Structural Equation Modeling. Jurnal sistem informasi.1 (1),1-20.

Yulianto,Subakdo Eko.(2011).Pengaruh Presepsi Kemudahan dan Presepsi Kemanfaatan Kepada Pemanfaatan E-learning dengan Menggunakan TAM. JBTI. 1(1). 